THE MORAL WITNESS 


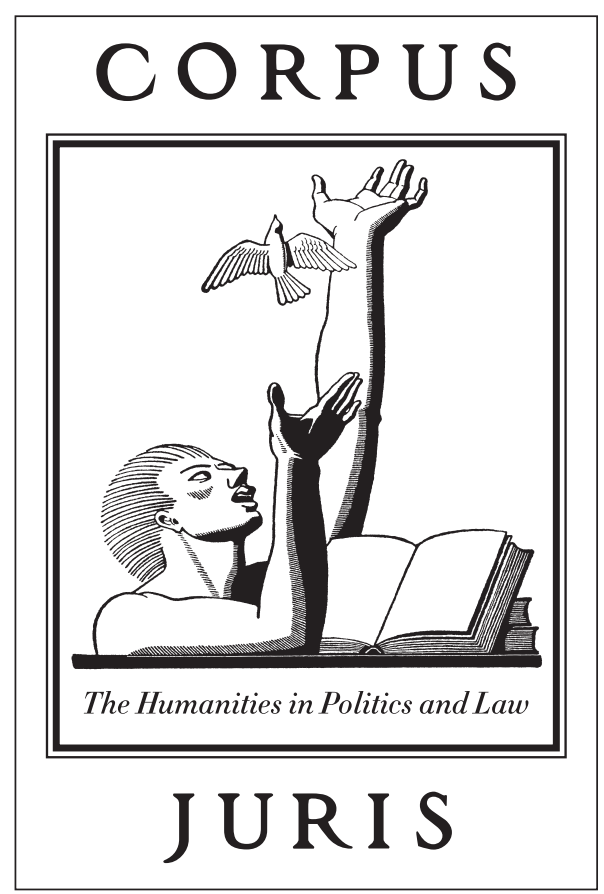

Series editor: Elizabeth S. Anker, Cornell University

CORPUS JURIS: THE HUMANITIES IN POLITICS AND LAW PUBLISHES BOOKS AT THE INTERSECTIONS BETWEEN LAW, POLITICS, AND THE HUMANITIES-INCLUDING HISTORY, LITERARY CRITICISM, ANTHROPOLOGY, PHILOSOPHY, RELIGIOUS STUDIES, AND POLITICAL THEORY. BOOKS IN THIS SERIES TACKLE NEW OR UNDERANALYZED ISSUES IN POLITICS AND LAW AND DEVELOP INNOVATIVE METHODS TO UNDERTAKE THOSE INQUIRIES. THE GOAL OF THE SERIES IS TO MULTIPLY THE INTERDISCIPLINARY JUNCTURES AND CONVERSATIONS THAT SHAPE THE STUDY OF LAW. 


\section{THE MORAL}

WITNESS

\section{Trials and Testimony after Genocide}

Carolyn J. Dean 


\section{Copyright (๑) 2019 by Cornell University}

All rights reserved. Except for brief quotations in a review, this book, or parts thereof, must not be reproduced in any form without permission in writing from the publisher. For information, address Cornell University Press, Sage House, 512 East State Street, Ithaca, New York 14850. Visit our website at cornellpress.cornell.edu.

First published 2019 by Cornell University Press

Printed in the United States of America

Library of Congress Cataloging-in-Publication Data

Names: Dean, Carolyn J. (Carolyn Janice), 1960- author.

Title: The moral witness : trials and testimony after genocide / Carolyn J. Dean.

Description: Ithaca [New York] : Cornell University Press, 2019. | Series: Corpus juris : the humanities in politics and law | Includes bibliographical references and index.

Identifiers: LCCN 2018042975 (print) | LCCN 2018047925

(ebook) | ISBN 9781501735080 (e-book pdf) | ISBN

9781501735097 (e-book epub/mobi) | ISBN 9781501735066 | ISBN 9781501735066 (cloth ; alk. paper) | ISBN 9781501735073 (pbk. ; alk. paper)

Subjects: LCSH: Genocide—Historiography. | Genocide—Moral and ethical aspects. | Witnesses. | Genocide survivors. | Trials (Genocide)

Classification: LCC HV6322.7 (ebook) | LCC HV6322.7 .D425 2019 (print) | DDC 345/.0251—dc23

LC record available at https://lccn.loc.gov/2018042975

Margarete Buber-Neumann testifies at the Kravchenko Trial, February 23, 1949. Photo by Keystone-France/GammaKeystone via Getty Images. Used by permission. 